\title{
Interpolasi Cubic Spline untuk Memetakan Distribusi Panas pada Permukaan Panel Sel Surya
}

\author{
BAYU ERFIANTO, ALDRY HERNANDA SETIAWAN
}

\author{
Fakultas Informatika Universitas Telkom, Indonesia \\ Email: erfianto@telkomuniversity.ac.id
}

Received 24 Maret 2020 | Revised 8 April 2020 | Accepted 25 Juli 2020

\begin{abstract}
ABSTRAK
Penelitian ini bertujuan untuk mengetahui sebaran atau distribusi panas yang terjadi pada permukaan panel surya atau photo voltaic (PV) dengan dengan data sebaran sensor yang diolah dengan metode interpolasi cubic spline, sehingga dapat digunakan untuk mengetahui posisi panel surya yang efektif dan ideal menerima cahaya matahari. Selain informasi panas pada panel surya juga informasi mengenai daya yang dikeluarkan oleh panel surya tersebut. Pemetaan distribusi panas pada panel PV menggunakan metode interpolasi cubic spline yang selanjutnya divisualisasikan dalam heatmap 2D. Berdasarkan heatmap hasil interpolasi dan hasil eksperimen menunjukkan panel PV pada posisi vertikal dengan kemiringin $0^{\circ}$ pukul 12.00-14.00 menghasilkan arus tertinggi yaitu 449.2mA dengan tegangan yang dihasilkan sebesar $1.03 \mathrm{~V}$ sehingga menghasilkan daya sebesar 0.46W. Hal ini lebih optimal dari suhu permukaan PV yang lebih panas pada pada posisi vertikal dengan kemiringin $45^{\circ}$ ataupun posisi horizontal $0^{\circ}$ dan $45^{\circ}$ pada jam yang sama.
\end{abstract}

Kata kunci: panel surya, heatmap, cubic spline, interpolasi

\begin{abstract}
This research aims to determine the distribution of heat that is exposed on the surface of solar panels or photo voltaic (PV), where the data from distributed sensor is processed by means of cubic spline interpolation method, so that it can be used to determine the ideal and effective position of solar panel to receive sunlight radiation. In addition to heat information on the solar panel, information about the power generated by PV is also measured. Based on the heatmap generated from the interpolation method and the experimental results, it shows that the PV panel in a vertical position with $0^{\circ}$ inclination at 12.00-14.00 produces the highest current which is $449.2 \mathrm{~mA}$ with the output voltage of $1.03 \mathrm{~V}$, thus the generated power is about $0.46 \mathrm{~W}$. This is more optimal than the surface temperature of the PV which is hotter in the vertical position with a $45^{\circ}$ or horizontal position with $0^{\circ}$ and $45^{\circ}$ at the same time.
\end{abstract}

Keywords: : solar panel, heatmap, cubic spline, interpolation 
Bayu Erfianto dan Aldry Hernanda Setiawan

\section{PENDAHULUAN}

Panel Surya merupakan perangkat yang digunakan pada pembangkit listrik tenaga surya, berfungsi untuk mengubah energi surya (matahari) menjadi energi listrik. Dalam sebuah panel surya ini terdapat sel photovoltaic (selanjutnya disingkat PV) atau biasa yang kita kenal adalah sel surya yang mempunyai peranan penting untuk memaksimalkan konversi cahaya matahari menjadi energi listrik (Shaker \& Ahmed, 2018). Sel PV ini akan mengeluarkan daya listrik sesuai dengan energi cahaya yang diterima. Namun, daya yang dikeluarkan tidak merata akibat panas dari cahaya matahari yang diterima juga tidak merata pada permukaan panel surya (Zaini, et al., 2015). Selain itu juga masih adanya menyangka jika PV ditempatkan pada tempat yang asal terkena sinar matahari terik akan menghasilkan tegangan dan arus listrik yang optimal, melainkan sebaliknya jika peletakan panel surya tidak benar maka akan hanya menghasilkan daya yang tidak optimal (Harits, 2015).

Beberapa solusi dari permasalahan tersebut adalah dengan melakukan variasi kemiringan panel surya untuk mencari kemiringan yang optimal terhadap arus dan tegangan yang dihasilkan (Harits, 2015) dan juga tracking panel surya terhadap pergerakan matahari beserta pemantauan arus dan tegangan yang dikeluarkan oleh panel surya tersebut (Saputra, Erfianto, Saputra, Prabowo, \& Swastika, 2019). Penelitian tersebut hanya menekankan pada sistem kendali agar panel surya dapat mengikuti arah pergerakan matahari, tetapi tidak melakukan pemantauan bagaimana pengaruh panas matahari terhadap arus yang dikeluarkan oleh panel surya. Penggunaan sensor suhu yang diletakkan pada permukaan PV untuk mengetahui temperatur permukaan panel serta pengaruhnya terhadap keluaran arus dan tegangan telah dilakukan oleh (Zaini, et al., 2015) dan (Mančić, Jovanović, \& Dragan, 2018). Paparan modul PV ke sinar matahari, jumlah energi dari matahari yang dikonversi menjadi energi bermanfaat adalah sekitar $31 \%$, namun persentase perubahan yang lebih besar menjadi energi panas, yang cenderung membuat suhu modul naik, dan ini menyebabkan pengurangan daya listrik yang dihasilkan oleh modul PV (Idoko, Anaya-Lara, \& McDonald, 2018) (Pujotomo, Isworo \& Diantari, Retno Aita, 2018). Berdasarkan penelitian tersebut, panas yang cukup pada permukaan panel akan menghasilkan keluaran arus dan tegangan yang besar. Namun pada kedua penelitian tersebut belum diketahui seperti apa distribusi atau sebaran panas pada permukaan PV terhadap variasi kemiringan panel surya dalam kaitannya dengan keluaran tegangan dan arus.

Penelitian ini bertujuan untuk mengetahui sebaran atau distribusi panas yang terjadi pada permukaan PV dengan data sebaran sensor yang diolah dengan metode interpolasi cubic spline, sehingga dapat digunakan untuk mengetahui posisi panel surya yang efektif dan ideal menerima cahaya matahari. Ideal yang dimaksud oleh penulis adalah daya yang dihasilkan oleh panel surya itu sendiri dengan posisi yang diubah-ubah. Posisi panel surya mengacu pada percobaan (Harits, 2015) yaitu dengan posisi kemiringan $0^{\circ}$ atau $45^{\circ}$ dengan posisi vertikal dan horizontal dan di tempat lapangan terbuka dan tegak lurus terhadap mata angin arah Timur. Sensor akan menangkap suhu di beberapa titik yang telah ditentukan, lalu data dikirim menuju web server secara berkala. Setelah data dikirimkan menuju server selanjutnya akan dibuat peta distribusi panas permukaan PV. Pembuatan peta distribusi atau peta sebaran panas tersebut menggunakan algoritma cubic spline yang selanjutnya divisualisasikan menggunakan heatmap 2D. 


\section{METODE PENELITIAN}

\subsection{Gambaran Umum Sistem}

Pada Gambar 1 menjelaskan gambaran umum sistem pemetaan panas pada panel surya. Terdapat dua belas sensor termal, yaitu DSB18B20, yang dipasang menempel pada permukaan PV. Sensor akan menangkap panas permukaan PV, lalu data termal permukaan dikirim mikrokontroler (ESP16), dimana data tersebut berikutnya diparsing oleh program yang tertanam dalam mikrokontroller untuk selanjutnya dikirim menggunakan protocol HTTP menuju web server pada komputer. Untuk pengambilan data arus dan tegangan yang dihasilkan oleh panel surya menggunakan sensor arus dan tegangan INA219, dimana pemasangannya dari panel surya dihubungkan ke solar cell controller. Tujuannya adalah jika daya dari panel surya melebihi kapasitas penerimaan baterai (dalam kondisi penuh misalnya), maka kontroler akan mengurangi atau memutus daya tersebut agar sesuai dengan kapasitas penerimaan baterai. PV yang digunakan adalah merek Sunny 10 WP 1A dengan dimensi 415 x 245 x $20 \mathrm{~mm}$. Dari sensor arus dan tegangan, data tentang arus dan tegangan selanjutnya dikirim ke mikrokontroler untuk digabungkan dengan data temperatur permukaan PV. Data arus, tegangan dan temperatur diproses oleh aplikasi untuk menjalankan program interpolasi dan pemetaan dengan hasil berupa gambar peta sebaran atau distribusi (heatmap) dan juga perhitungan daya yang dikeluarkan oleh panel surya menuju baterai. Pembuatan heatmap menggunakan metode cubic spline selanjutnya dibahas pada bab berikutnya.

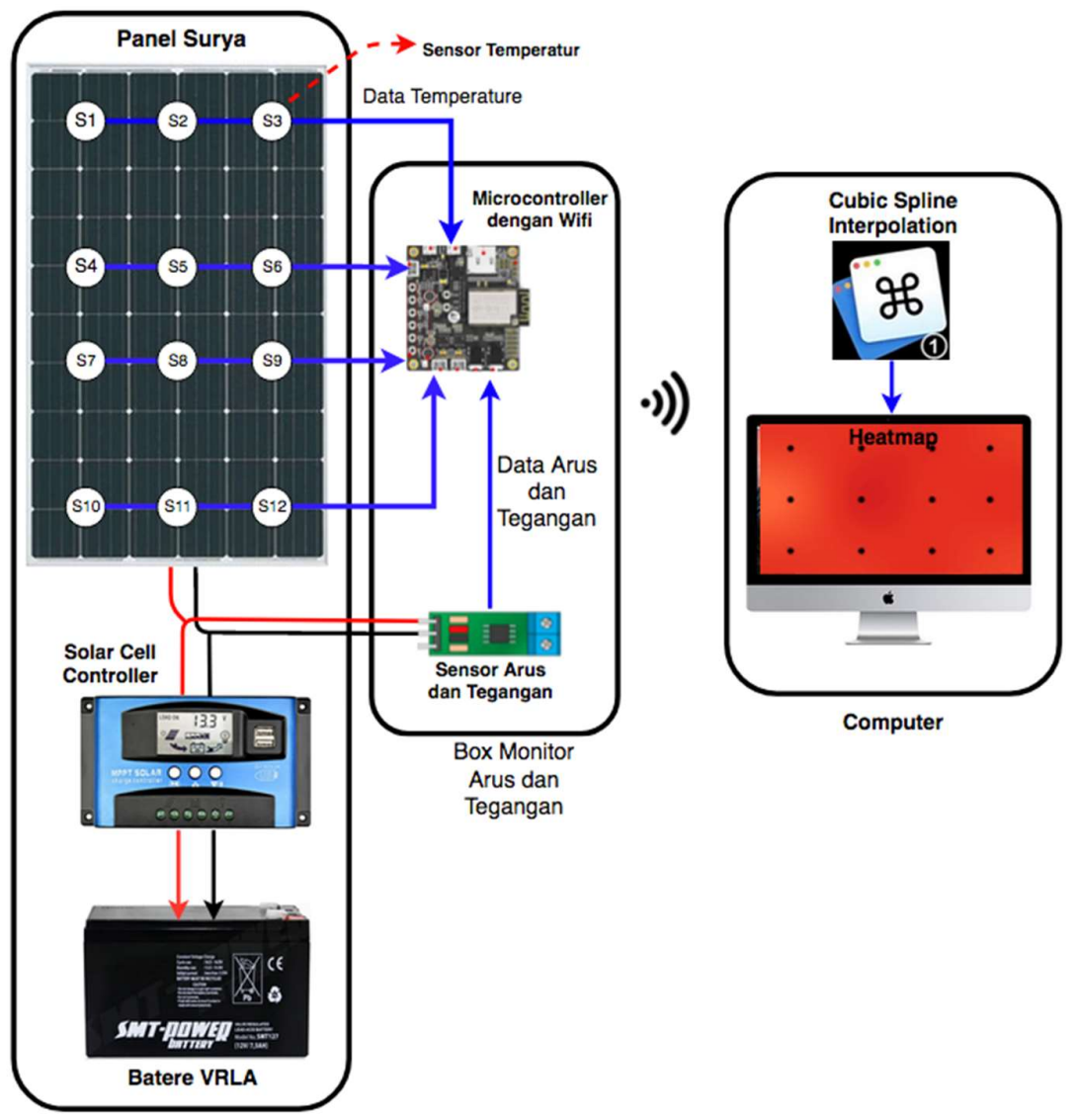

Existing System

Gambar 1. Sistem yang Dibangun 


\subsection{Metode Interpolasi Kubik}

Heatmap adalah sebuah peta distribusi yang dibangkitkan oleh metode interpolasi dua dimensi (Mangeni, et al., 2017), dalam hal ini adalah peta sebaran suhu dari sensor yang telah diletakkan pada permukaan PV. Pada makalah tersebut pemetaan distribusi panas dilakukan dengan teknik interpolasi linear. Interpolasi pada kasus ini adalah menghitung suhu di antara dua titik sensor. Tujuan interpolasi ini untuk meminimalisir biaya karena tidak perlu banyak sensor yang digunakan hanya beberapa titik saja. Pada kasus ini distribusi suhu akan dilakukan dengan cubic spline. Heatmap juga dibuat dengan cara pengelompokan data-data, pengelompokan heatmeap terdiri dari baris dan kolom sehingga membentuk data matriks (Sharko, Grinstein, Marx, \& Zhou, 2007). Data matriks berisikan data suhu yang didapatkan oleh sensor suhu. Lalu data sensor akan diklasifikasikan ke dalam bentuk warna. Semakin panas suhu maka warna yang dihasilkan akan menjadi lebih merah, selain itu juga jika suhu semakin dingin maka warna akan menjadi lebih condong ke arah warna biru.

Interpolasi cubic spline adalah interpolasi yang lebih tinggi presisinya dibandingkan dengan interpolasi lainnya hal ini dikarenakan orde tetangga yang digunakan oleh interpolasi ini adalah tiga (Phillips, 2000). Nilai-nilai dari orde ini nantinya akan digunakan pada node bayangan yang seakan-akan ada pada panel surya tersebut. Berikut persamaan cubic spline secara umum yang digunakan:

$$
p(x)=d_{i}+(x) c_{i}+(x)^{2} b_{i}+(x)^{3} a_{i}
$$

Dari Persamaan (1) di atas dapat ditarik kesimpulan bahwa metode cubic spline adalah membagi interval fungsi menjadi sub interval yang dimana setiap sub-sub interval akan dicari nilai a,b,c,dan d, setelah itu nantinya akan disatukan menjadi persamaan polinomial yang utuh yang dimana nilai $x$ adalah data suhu yang sudah disimpan dalam database. Setalah nilai-nilai tersebut diketahui, berikutnya adalah kita dapat mengetahui berapa nilai suhu yang diestimasi pada sekitar sensor tersebut. Berikut perbedaan hasil peta panas menggunakan interpolasi cubic spline dengan metode interpolasi yang lainnya (Sharko, Grinstein, Marx, \& Zhou, 2007).

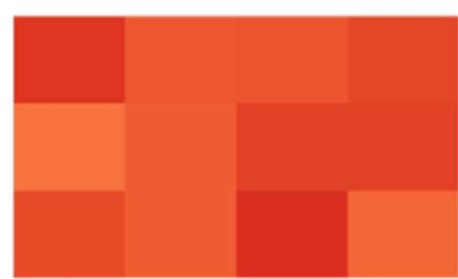

(a)

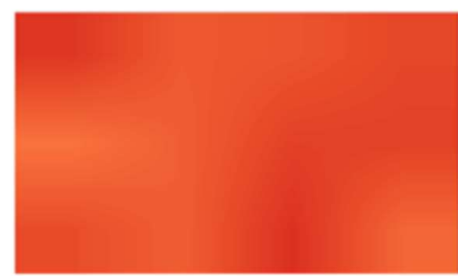

(b)

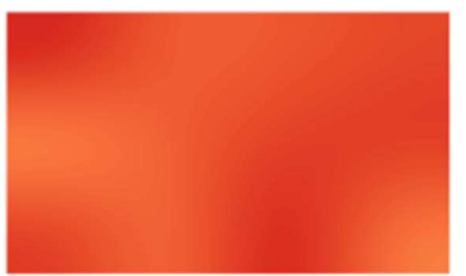

(c)

\section{Gambar 2. Visualisasi Heatmap (a) Metode Nearest Neighbor (b) Linear (c) Cubic Spline}

Penelitian ini melanjutkan penelitian yang sudah dilakukan sebelumnya (Saputra, Erfianto, Saputra, Prabowo, \& Swastika, 2019). Pada penelitian tersebut menggunakan penelitian yang serupa dengan penulis tetapi pada jurnal tersebut menggunakan teknik interpolasi linear sedangkan penulis pada penelitian ini menggunakan teknik interpolasi cubic spline yang dimana teknik tersebut memiliki tingkat presisi yang lebih baik. Penggunaan sensor suhu DS18B20 mengacu pada (Saputra, Erfianto, Saputra, Prabowo, \& Swastika, 2019). Sedangkan untuk pemilihan sensor tegangan dan arus INA219 merujuk pada jurnal (Cholish \& Sara, 2016) karena sensor ini dapat menghitung arus dan tegangan secara bersamaan. Adapun penggunaan sensor suhu DS18B20 dikarenakan sensor ini lebih tahan terhadap cuaca di luar ruangan. Untuk pembuatan peta panas (heatmap) penulis menggunakan algoritma 
cubic-spline, karena berdasarkan organisasi open source Python (Zhao, Guo, Sheng, \& Shyr, 2014) menjelaskan bahwa algoritma tersebut lebih baik dibandingkan algoritma pembuatan heatmap lainnya.

\section{HASIL DAN ANALISIS}

Berdasarkan hasil eksperimen yang dilakukan oleh (Harits, 2015) bahwa kemiringan yang ideal untuk pemasangan panel surya adalah $45^{\circ}$ dan juga $0^{\circ}$ dengan arah kemiringan ke arah barat. Maksud dari ideal ini adalah posisi panel surya yang menghasilkan daya yang paling besar dibandingkan dari skenario-skenario lainnya. Selain itu juga dilakukan dengan posisi vertikal dan horizontal untuk masing-masing kemiringan. Dengan adanya kemiringan panel surya terhadap tanah tentu mempengaruhi panas matahari yang mengenai permukaan panel surya karena panas matahari dari siang menuju sore hari lebih panas dibandingkan dari pagi menuju siang hari. Selain itu juga pemasangan vertikal dan horizontal mempengaruhi daya yang dikeluarkan oleh panel surya, hal ini dikarenakan saat sinar matahari bergerak dari timur menuju barat pada posisi vertikal mengenai bagian atas permukaan panel surya sedangkan pada posisi horizontal akan mengenai bagian samping panel surya. Tentu hal tersebut akan membedakan daya yang dihasilkan oleh panel surya. Adapun contoh ilustrasi pemasangan panel saat eksperimen dapat dilihat pada Gambar 3. Berikut adalah skenario yang dilakukan pada penelitian ini:

1. Kemiringan $0^{\circ}$ dengan posisi horizontal.

2. Kemiringan $0^{\circ}$ dengan posisi vertikal.

3. Kemiringan $45^{\circ}$ dengan posisi vertikal arah barat.

4. Kemiringan $45^{\circ}$ dengan posisi horizontal arah barat.

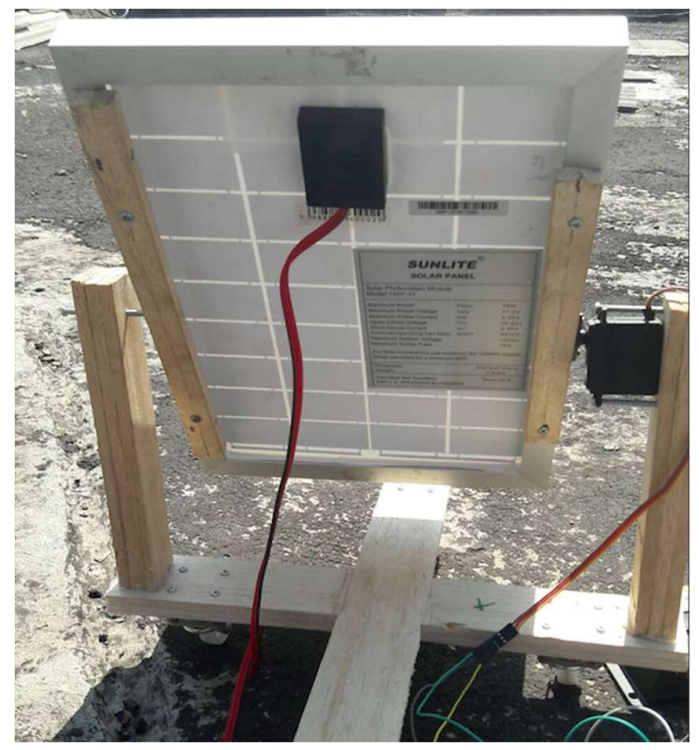

Gambar 3. Ilustrasi Pemasangan Solar Panel pada Saat Eksperimen. Ilustrasi Ini adalah pada Skenario 3: Kemiringan $4^{\circ}$ Posisi Vertikal Arah Barat 


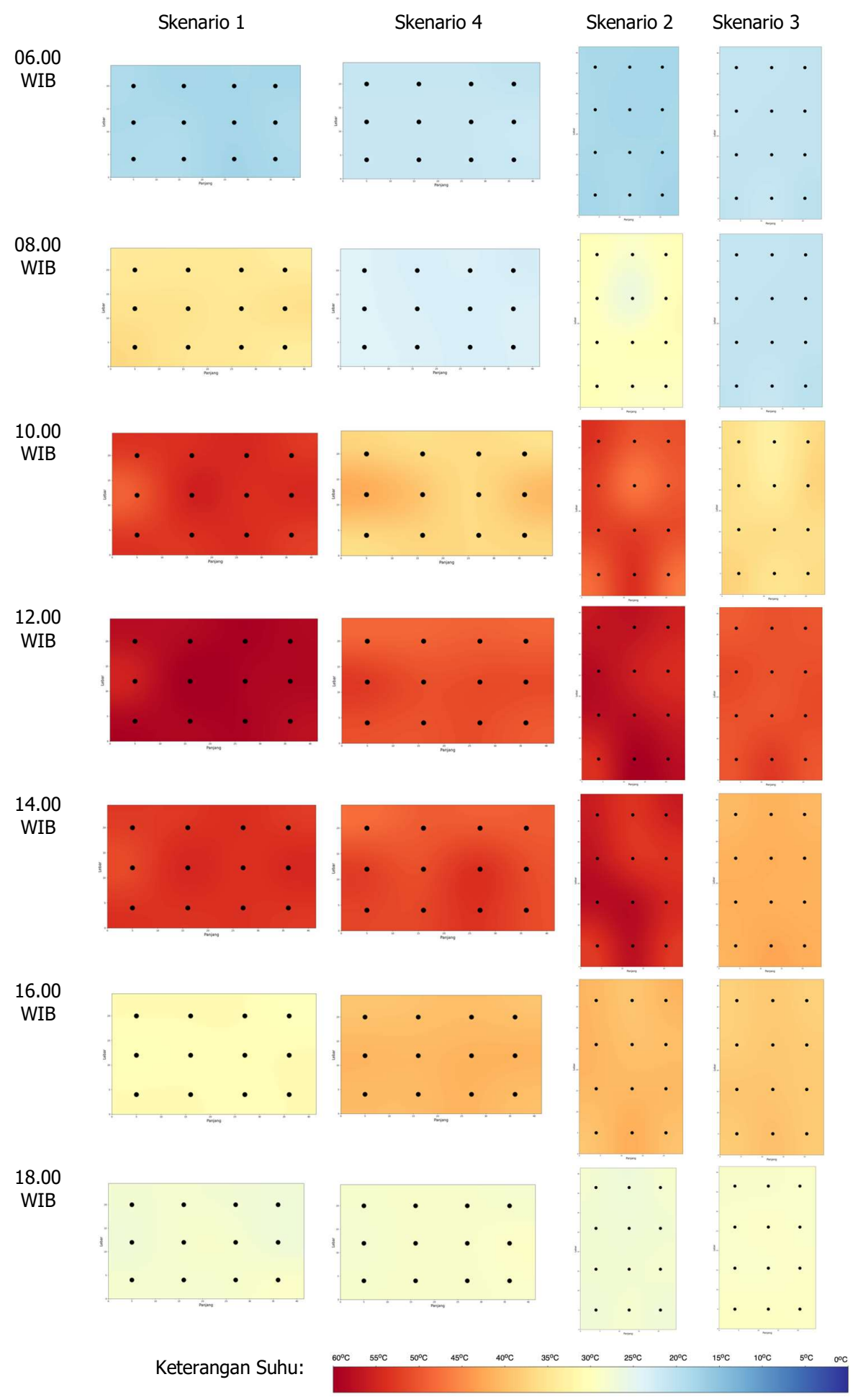

Gambar 4. Sebaran Suhu di Permukaan PV pada Empat Skenario Eksperimen

Keempat skenario tersebut sudah mewakili instalasi panel surya pada umumnya masyarakat (Shaker \& Ahmed, 2018). Skenario dijalankan dari jam enam pagi sampai dengan jam enam malam, karena sistem berjalan berdasarkan matahari terbit hingga matahari terbenam. Adapun eksperimen dilakukan di roof-top Gedung E Panambulai - Fakultas Informatika, Universitas Telkom. Setiap dua jam sekali sistem akan mengirimkan data berupa ID dari sensor 
node, suhu permukaan PV yang ditangkap oleh setiap sensor node, arus, tegangan, dan juga daya terhitung, sehingga pada satu hari akan menghasilkan tujuh data. Skenario dijalankan pada pengujian dapat dilihat pada Tabel 1.

Tabel 1. Waktu Eksperimen

\begin{tabular}{|c|c|c|c|c|c|}
\hline $\begin{array}{c}\text { Skenario } \\
\text { Eksperimen }\end{array}$ & $\begin{array}{c}\text { Tgl } \\
\text { Eksperimen }\end{array}$ & $\begin{array}{c}\text { Waktu Mulai } \\
\text { (WIB) }\end{array}$ & $\begin{array}{c}\text { Waktu Selesai } \\
\text { (WIB) }\end{array}$ & $\begin{array}{c}\text { Kemiringan } \\
\text { Panel }\end{array}$ & $\begin{array}{c}\text { Posisi } \\
\text { Panel }\end{array}$ \\
\hline 1 & $3-09-2019$ & 06.00 & 18.00 & $0^{\circ}$ & Horizontal \\
\hline 2 & $6-09-2019$ & 06.00 & 18.00 & $0^{\circ}$ & Vertikal \\
\hline 3 & $18-09-2019$ & 06.00 & 18.00 & $45^{\circ}$ & $\begin{array}{c}\text { Vertikal arah } \\
\text { barat }\end{array}$ \\
\hline 4 & $19-09-2019$ & 06.00 & 18.00 & $45^{\circ}$ & $\begin{array}{c}\text { Horizontal } \\
\text { arah barat }\end{array}$ \\
\hline
\end{tabular}

Hasil eksperimen kemudian divisualisasikan dalam bentuk distribusi suhu permukaan PV melalui heatmap. Dapat dilihat pada heatmapyang dihasilkan pada skenario satu bahwa suhu terendah berada pada pukul 06.00 karena menghasilkan warna dominan biru (suhu rendah) dan suhu tertinggi pada pukul 12.00. Naik dan turunnya suhu juga mempengaruhi tegangan dan arus yang dihasilkan oleh panel surya bahwa semakin rendah suhu maka arus akan mengecil dan semakin tinggi suhu maka semakin tinggi arus listrik yang dihasilkan. Sedangkan dampak pada tegangan listrik yaitu semakin mendekati suhu standar panel surya $(25 \circ \mathrm{C})$ maka tegangan yang dihasilkan akan semakin besar dan bila semakin panas maka tegangan mengecil, sesuai dengan eksperimen (Idoko, Anaya-Lara, \& McDonald, 2018) (Mangeni, et al., 2017) (Zaini, et al., 2015). Adapun contoh hasil pemetaan heatmap interpolasi distribusi panas pada permukaan panel PV dari skenario 1 sampai dengan skenario 4 dapat dilihat pada Gambar 4.

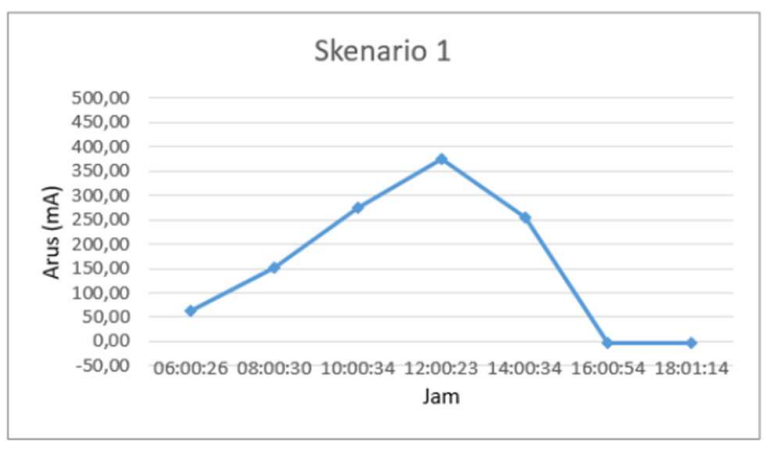

Skenario 2

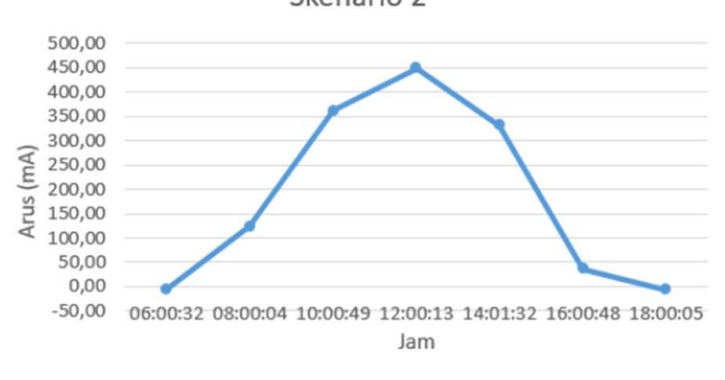

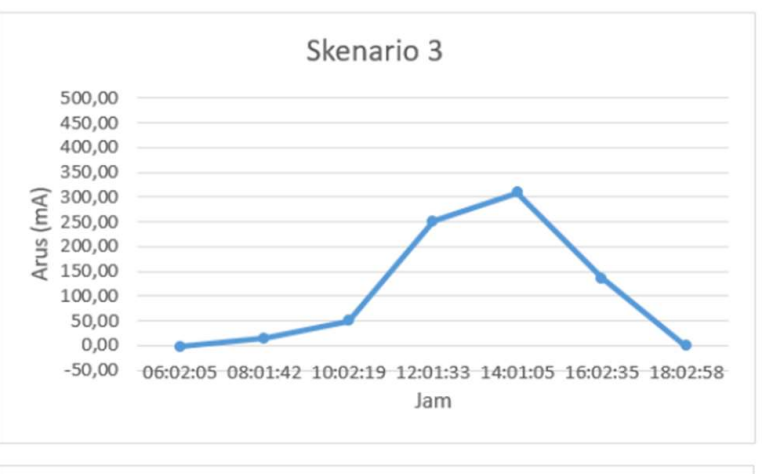

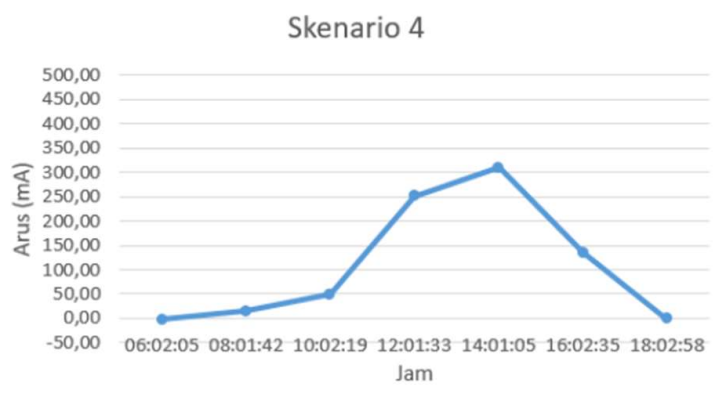

Gambar 5. Besar Arus Listrik berdasarkan Pola Distribusi Panas Panel Surya 
Adapun untuk keluaran arus dan tegangan berdasarkan visualisasi heatmap tersebut dapat dilihat pada Gambar 5 dan Gambar 6. Pada eksperimen didapat arus tertinggi dihasilkan pada skenario satu adalah $350 \mathrm{~mA}$ pada pukul 12.00 , pada skenario dua adalah $450 \mathrm{~mA}$ pada pukul 12.00 , pada skenario tiga adalah $300 \mathrm{~mA}$ pada pukul 14.00, dan pada skenario 4 adalah $300 \mathrm{~mA}$ pada pukul 14.00. Selain itu juga pada pagi hari dan sore hari tidak dapat mengalirkan arus karena arus yang dihasilkan adalah $0 \mathrm{~mA}$.

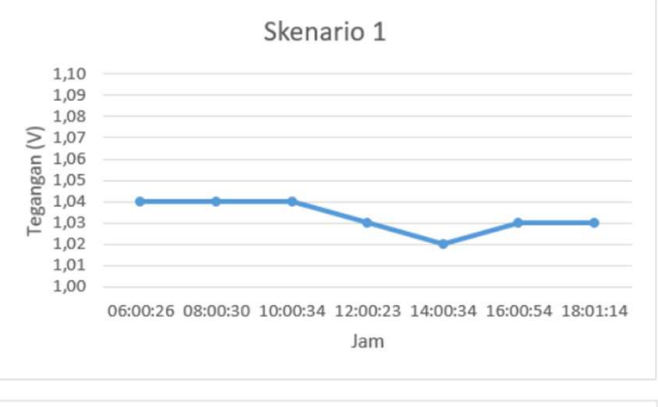

Skenario 2

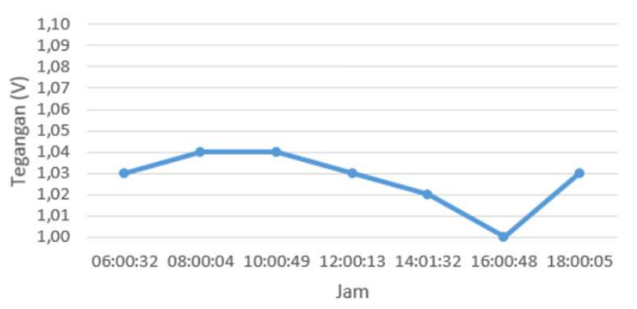

Skenario 3

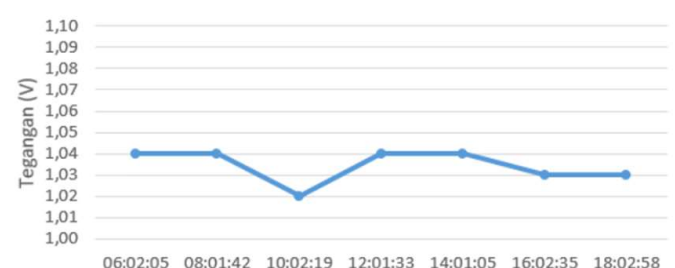

Jam

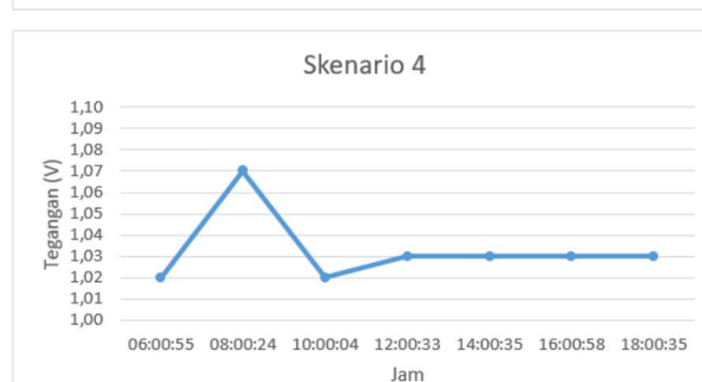

\section{Gambar 6. Besar Tegangan berdasarkan Pola Distribusi Panas Panel Surya}

Pada eksperimen terlihat bahwa didapat tegangan tertinggi pada skenario satu adalah $1.04 \mathrm{~V}$ pada pukul 06.00 sampai 10.00 , pada skenario dua adalah $1.04 \mathrm{~V}$ pada pukul 08.00 sampai 10.00 , pada skenario tiga adalah $1.04 \mathrm{~V}$ pada pukul 06.00 sampai 08.00 dan juga dari pukul 12.00 sampai 14.00 , dan pada skenario empat adalah 1.07 pada pukul 08.00. Perbedaan tegangan keluaran yang dihasilkan oleh panel surya disebabkan oleh pengaruh suhu pada permukaan panel surya. Hal ini dapat dikonfirmasi dengan heatmap hasil interpolasi pada percobaan 1 dan percobaan 4 (lihat Gambar 4) pada pukul 12.00 sampai 14.00 dimana heatmap hasil interpolasi permukaan PV pada percobaan satu menunjukkan hasil yang lebih panas (merah tua) dengan distribusi panas yang merata pada permukaan PV. Sehingga, tegangan yang dihasilkan pada percobaan 1 lebih rendah dari percobaan 4. Penurunan tegangan akibat paparan panas matahari juga berlaku pada percobaan 2 dengan posisi PV diletekkan secara vertikal.

Dari eksperimen tersebut telah dibangkitkan atau dihasilkan heatmap dengan ukuran piksel 1239x731 untuk posisi horizontal dan 911x1545 untuk posisi vertikal. Berdasarkan eksperimen yang telah dilakukan serta heatmap hasil interpolasi pada Gambar 3 dapat disimpulkan bahwa posisi ideal untuk meletakkan panel PV adalah dengan posisi vertikal dengan kemiringan $0^{\circ}$ (Skenario 2) dan arus optimal yang dihasilkan pada pukul 12.00 yaitu 449,2 mA dan menghasilkan tegangan $1.03 \mathrm{~V}$. Selain itu juga pada skenario eksperimen tersebut juga dapat disimpulkan bahwa PV tidak dapat mengalirkan daya pada pagi hari pukul 06.00 WIB dan juga sore hari pukul 18.00 WIB, hal ini dikarenakan tidak adanya sinar matahari yang mengekspos permukaan panel PV. 


\section{KESIMPULAN}

Pada penelitian ini telah dikembangkan metode interpolasi cubic spline untuk menginterpolasi data suhu permukaan panel PV serta memvisualisasikannya dalam peta distribusi atau sebaran heatmap 2D. Visualisasi warna pada heatmap merepresentasikan data suhu pada permukaan PV. Teknik interpolasi ini juga memungkinkan untuk memvisualisasikan heatmap yang lebih halus dan jika titik sensor semakin banyak maka semakin akurat hasil interpolasi dan visualisasi yang dihasilkan. Pada penelitian ini menggunakan 12 titik sensor termal yang diletakkan pada pada panel PV 10WP. Pada penelitian ini juga dilakukan pengukuran arus dan tegangan keluaran PV. Hasil eksperimen menunjukkan pada posisi vertikal dengan kemiringin $0^{\circ}$ pukul 12.00 menunjukkan arus tertinggi yaitu $449.2 \mathrm{~mA}$ dengan tegangan yang dihasilkan sebesar $1.03 \mathrm{~V}$ sehingga menghasilkan daya sebesar $0.46 \mathrm{~W}$. Hal ini lebih optimal dari suhu permukaan PV yang lebih panas pada skenario 1 dan skenario 4 pada jam yang sama. Oleh karena itu posisi yang lebih baik untuk penerapan panel surya yaitu seperti skenario 2. Untuk pengembangan selanjutnya dapat menggunakan panel surya dengan ukuran 10WP dengan dilengkapi kemampuan solar tracker untuk menyesuaikan terhadap pergerakan matahari. Selain itu juga sistem yang dibangun dapat terkoneksi dengan internet sehingga pengguna dapat mengetahui daya yang dihasilkan setiap harinya dan berapa daya yang sudah tersimpan pada baterai.

\section{DAFTAR RUJUKAN}

Cholish, Y., \& Sara, I. D. (2016). Perancangan Alat Pencatat Data Kurva Karakteristik Arus dan Tegangan Modul Surya. Universitas Syiah Kuala.

Harits. (2015). Pengaruh Kemiringan Matahari terhadap Energi Listrik yang Dihasilkan Solar Cell. Retrieved from: http://old.technonatura.sch.id/node/925.

Idoko, L., Anaya-Lara, O., \& McDonald, A. (2018). Enhancing PV modules efficiency and power output using multi-concept cooling technique. Energy Reports, 4, 357-369.

Mančić, U. J., Jovanović, I., \& Dragan. (2018). Overview of Temperature Sensors for Temperature Measurement of PV Modules. 26th IEEE Telecommunications Forum (TELFOR), (pp. 1--8).

Mangeni, G., Tan, R., Tan, T., Cheo, S., Mok, V., \& Pang, J. Y. (2017). Photovoltaic module cell temperature measurements using linear interpolation technique. 2017 IEEE International Instrumentation and Measurement Technology Conference (I2MTC), (pp. $1--6)$.

Phillips, G. M. (2000). Interpolation and Approximation by Polynomials. New York:Springer.

Pujotomo, I., \& Diantari, R. A. (2018). Characteristics Surface Temperature of Solar Cell Polycrystalline Type to Output Power. EDP E3S Web of Conferences.

Saputra, A., Erfianto, B., Saputra, M., Prabowo, S., \& Swastika, N. A. (2019). Implementasi Fuzzy Logic Control Pada Pelacakan Panel Surya. Jurnal Teknologi Bahan dan Barang Teknik, $9(1)$. 
Shaker, Z., \& Ahmed, A. (2018). Solar Celss and Arrays: Principles, Analysis and Design. Dalam I. Yahyaoui, Advances in Renewable Energies and Power Technologies (pp. 3-56).

Sharko, J., Grinstein, G., Marx, K. A., \& Zhou, J. a.-H.-G. (2007). Heat map visualizations allow comparison of multiple clustering results and evaluation of dataset quality: Application to microarray data. 11th IEEE International Conference Information Visualization (IV'07), (pp. 521--526).

Zaini, N., Ab Kadir, M., Izadi, M., Ahmad, N., Radzi, M., \& Azis, N. (2015). The effect of temperature on a mono-crystalline solar PV panel. IEEE Conference on Energy Conversion (CENCON), (pp. 249--253). IEEE.

Zhao, S., Guo, Y., Sheng, Q., \& Shyr, Y. (2014). Advanced heat map and clustering analysis using heatmap3. BioMed Research International. 